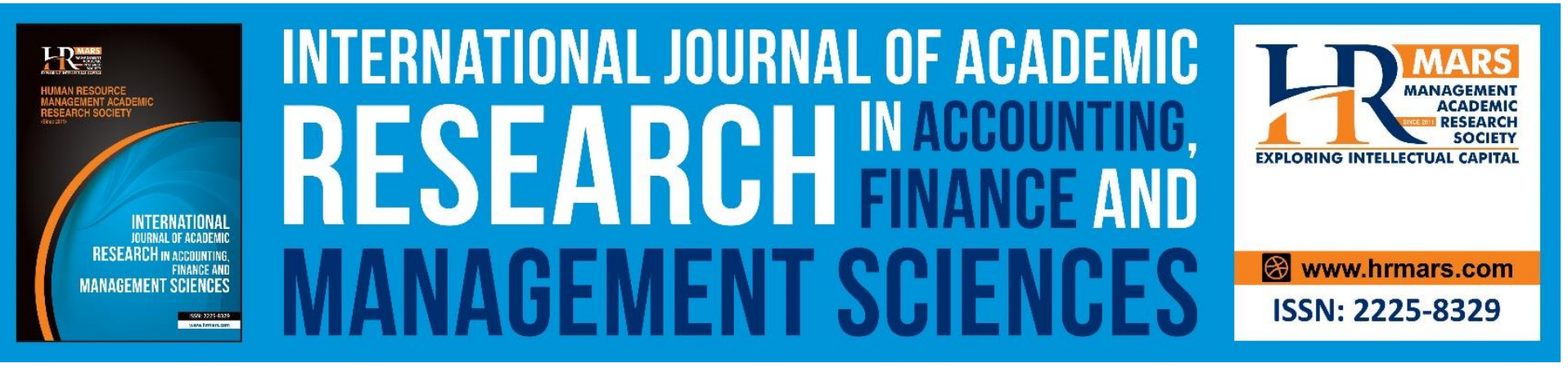

\title{
Strategic Planning and Revenue Diversification Capacity of National Sports Federations in Kenya
}

\author{
Mark Ouche Obonyo
}

To Link this Article: http://dx.doi.org/10.6007/IJARAFMS/v11-i2/9182

DOI:10.6007/IJARAFMS /v11-i2/9182

Received: 10 March 2021, Revised: 13 April 2021, Accepted: 26 April 2021

Published Online: 20 May 2021

In-Text Citation: (Obonyo, 2021)

To Cite this Article: Obonyo, M. O. (2021). Strategic Planning and Revenue Diversification Capacity of National Sports Federations in Kenya. International Journal of Academic Research in Accounting Finance and Management Sciences, 11(2), 106-122.

Copyright: (C) 2021 The Author(s)

Published by Human Resource Management Academic Research Society (www.hrmars.com)

This article is published under the Creative Commons Attribution (CC BY 4.0) license. Anyone may reproduce, distribute, translate and create derivative works of this article (for both commercial and non-commercial purposes), subject to full attribution to the original publication and authors. The full terms of this license may be seen at: http://creativecommons.org/licences/by/4.0/legalcode

Vol. 11, No. 2, 2021, Pg. 106 - 122

http://hrmars.com/index.php/pages/detail/IJARAFMS

JOURNAL HOMEPAGE

Full Terms \& Conditions of access and use can be found at http://hrmars.com/index.php/pages/detail/publication-ethics 


\title{
Strategic Planning and Revenue Diversification Capacity of National Sports Federations in Kenya
}

\author{
Mark Ouche Obonyo \\ Faculty of Business and Economics Tom Mboya University College, Kenya
}

\begin{abstract}
Building revenue diversification capacity for an organization requires management to engage in strategic planning that create innovative programs and services, build resilience against adverse conditions, and establish a sustainable financial performance. However, previous studies show that managers of most nonprofit sports organizations lack requisite strategies for developing diversified financial portfolios to achieve sustainability. Enactment of sports Act 2013 in Kenya made it mandatory for all registered National Sports Federations (NSFs) to engage in strategic planning with the hope of improving their performance generally and revenue streams in particular, which has remained elusive. The purpose of this study was to analyze effect of strategic planning on revenue diversification capacity of NSFs through the lens of Markowitz's modern portfolio theory and resource dependence theory espoused by Pfeffer and Salancik's (1978). The study employed descriptive and correlation research designs. A target population of 156 officials from 39 National Sports Federations (NSFs) was used. A sample of 144 respondents was randomly picked using Fisher's model. Primary data was collected using structured questionnaire and analysis of financial documents. Descriptive statistics involving percentages were run. Multiple regression analysis was employed to analyze the effect of strategic planning on revenue diversification capacity of NSFs in Kenya. The study established that there was significant and positive correlation between formulation of strategies and revenue diversification at $r=0.488 ; p=0.005$. However, correlation between other components of strategic planning (establishing strategic planning platform, strategy implementation, and monitoring and evaluation revealed insignificant positive linear relationship implying that the NSFs in Kenya although formulated strategies aimed at diversifying their revenue base, they did not consider the relevance of financing strategies to their industry environment which could be revealed by establishing strategic planning platform. The financing strategies were also not consistently implemented and consequently not monitored and evaluated. When effect of strategic planning was tested against revenue sources as a proxy of revenue diversification the effect was insignificant $(B=$ 0.189 , Beta $=0.110 ; p=0.544$ ) although a positive relationship between strategic planning and financial sources $(R=0.110)$ existed. The $R^{2}$ value of 0.012 indicated that strategic planning influenced only $1.20 \%$ of the decisions on financial sources in the case of NSFs in Kenya implying that strategic planning lacked intensity hence, the low revenue diversification capacity.
\end{abstract}


INTERNATIONAL JOURNAL OF ACADEMIC RESEARCH IN ACCOUNTING, FINANCE AND

MANAGEMENT SCIENCES

Vol. 11, No. 2, 2021, E-ISSN: 2225-8329 @ 2021 HRMARS

Keywords: Revenue Diversification Capacity, Strategic Planning, National Sports Federations, Sustainable Financial Performance

\section{Background}

National Sports Federations confront an array of performance pressures from the public, the federations' members and the government. The players expect the sporting objectives to be met through provision of better facilities, high quality competitions and good care during national team engagements. The public want subscribe to high quality and well managed games in terms of their consumption and demand good representation in global competitions. Escalating pressures from the government include production of world class athletes or teams against restricted funding. To sustain themselves NSFs are pressured to in turn increase their revenue generation.

Strategic planning is critical in managing the sport organizations' if they have to deliver on the stakeholder expectations and sustain their performance (Ferkins, Shilbury, \& McDonald, 2005; Hoye, 2006; Hoye \& Auld, 2001). Enactment of Sports Act 2013 in Kenya made it mandatory for all registered National Sports Federations (NSFs) to engage in strategic planning with the hope of improving their performance generally and revenue streams in particular, which has remained elusive. The ability of NSFs to achieve sustainable financial performance requires that they develop sound strategies to attract revenue from external sources; similarly their ability to innovatively generate revenue from the traditional internal sources must be planned for (Stewart, 2007).

Gerrard (2005) carried out a study on resource-utilization model of organizational efficiency in professional sports teams. The findings revealed that a good financial performance for a sport organization can be derived from a careful revenue diversification and cost reduction strategy. Barajas and Rodriguez (2010) and Dietl and Franck (2007) support the view by pointing out that professional sport clubs investing heavily in sporting performance at the expense of their revenue diversification capacity had financial problems.

Hoye and Cuskelly (2007) recognized that globalization has provided enormous opportunity for NSFs to diversify their revenue sources. They posited that the way sport is produced and consumed has greatly changed. Spectators and television audiences interested in elite sport events such as Olympic and Commonwealth games, world championships and world cups for a number of sports that enjoy unprecedented media coverage could be harnessed to provide unique revenue streams. They identified that NSFs could generate revenues through partnerships with television networks; radio broadcasters, internet service providers and mobile phone applications. This view is supported by Stewart (2007) who observed that a wide audience access information about favourite players and teams from newspapers and dedicated sport magazines and receive audio and visual progress scores, commentaries, highlight packages or real time broadcasts through mobile phone networks. Hoye and Cuskelly (2007) hence, provide an indication that revenue diversification could also be achieved through development of a viable financial structure and allocation of financial resources to revenue generating activities and programmes.

Winfree and Rosentraub (2012); European Union Commission (2011) in assessing the financial structure of sport organizations in member states of the European Union alluded that sports organizations could diversify their revenue sources through membership fees and other expenditures by households; contribution from volunteers; public sector funding, at national, regional and local levels; revenues from levies and charges on lotteries, betting and gambling operators; revenue from 
INTERNATIONAL JOURNAL OF ACADEMIC RESEARCH IN ACCOUNTING, FINANCE AND MANAGEMENT SCIENCES

Vol. 11, No. 2, 2021, E-ISSN: 2225-8329 @ 2021 HRMARS

sponsorship, patronage and donations; and revenue from media rights. The funds can be grouped in terms of funds from operations, funds from borrowings, funds from government and funds from corporate sponsors.

Peters (2004) looked at a good practice guide for sport organizations in Australia and concluded that revenue diversification could be achieved through purposeful allocation (utilization) of financial resources and budgets. Allocation must be in line with the level of strategic focus and the degree and direction of anticipated change in revenue conditions, and status or attainment of specific financial performance goals set by the management. Good utilization of funds derives from effective financial planning which articulates long-term objectives and takes care of short-term commitments (Peters, 2004). Short-term planning is realized through a monthly cash flow budget which monitors financial utilization on a monthly basis, while an annual projected operating budget is used to allocate funds to strategic priority areas and to project annual financial results over a yearly period.

Wicker and Breuer (2013) say that the relationship between sporting and financial performance through enhanced revenue diversification has often elicited controversy in research. Some scholars contend that emphasis on revenue diversification is likely to interfere with sport related goals. In a subsequent study, Wicker and Breuer (2013) applied financial portfolio theory (Markowitz, 1952), and looked at the effect of revenue diversification on the financial performance of National Sport Federations in Germany $(n=1,080)$. They concluded that revenue diversification had a positive effect on the financial condition of NSFs. Financial condition was measured in terms of total revenues, break even, profit, and investments for sport governing bodies. Their assertion was that financial risk could be decreased by diversifying revenue portfolio of NSFs. This implies that NSFs' could generate revenues from multiple sources and reduce their financial risk by relying on revenues of different risk levels.

Galaskiewicz and Bielefeld (1998) observed that revenue streams differ regarding their financial risk since some revenues are typically of higher risk and some are of lower risk. By mixing revenue streams of different risk levels the organization reduces its overall financial risk. Yet, an important precondition of this assumption is that revenue streams must not be correlated; high correlation among income streams would make the idea of diversification redundant.

Studies by Carroll and Stater (2008); Chang and Tuckman (1996); and Fischer, Wilsker, and Young (2011) examined revenue diversification among nonprofit organizations in several industries outside sport. The studies showed that the composition of the revenue mix is mirrored in the nature of the organization's services. For example, organizations providing public services rely more heavily on donations (Fischer et al., 2011). Also, the level of revenue diversification depends on the type of activity; nonprofits that rely heavily on donations and program service revenues were found to have less diversified revenues (Chang \& Tuckman, 1996). Carroll and Stater (2008); and Chang and Tuckman (1996) measured revenue diversification in terms of the Herfindahl index. This index is calculated by adding up the squared proportions of each revenue category. Originally, the index measures revenue concentration; therefore, the value should be subtracted from 1 that it is a diversification measure. The studies reported a low to medium level of revenue diversification among nonprofits $M=0.30$ (Carroll \& Stater, 2009). Moreover, the level of revenue diversification differs among nonprofit organizations in different industries (Chang \& Tuckman, 1996). For example, average revenue diversification was $\mathrm{M}=0.29$ in the health sector and in the community improvement/capacity building sector, whereas a mean value of 0.42 was measured in the public safety sector (Chang \& Tuckman, 1996). Chang and Tuckman (1996) further examined the effects of 
INTERNATIONAL JOURNAL OF ACADEMIC RESEARCH IN ACCOUNTING, FINANCE AND MANAGEMENT SCIENCES

Vol. 11, No. 2, 2021, E-ISSN: 2225-8329 ๑ 2021 HRMARS

revenue diversification on financial performance of organizations and found that organizations with more diversified revenues had a stronger financial position, were less financially vulnerable (Greenlee \& Trussel, 2000; Tuckman \& Chang 1991; Trussel, 2002), and had a lower insolvency risk (Keating et al., 2005).

Wicker and Breuer (2013); Carroll and Stater (2008); Chang and Tuckman (1996); Fischer, Wilsker, and Young (2011); Gerrard (2005), Barajas and Rodriguez (2010), and Dietl and Franck (2007) concluded that revenue diversification impacts positively on financial performance. On the contrary, Russell and Graham (2007); and Stewart (2007) looked at effect of globalization and technology on revenue diversification capacity of sport organizations and the two factors had created enormous opportunities for sport organizations to diversify their revenue sources. Winfree and Rosentraub (2012) identified revenue sources for sport organizations and classified the sources in terms of funds from operations, funds from borrowings, funds from government and funds from corporate sponsors. Peters (2004) looked at the role of purposeful allocation of financial resources and budgets in achieving revenue diversification. While, Galaskiewicz and Bielefeld (1998) concluded that the benefits of revenue diversification capacity to organizations depended on the revenue mix used in the diversification process since different revenue sources had varied levels of financial risks.

Whereas the studies reviewed above are agreed that revenue diversification is an indicator of financial performance, none of the studies demonstrated the link between strategic planning and revenue diversification capacity of both sport and non-sport organizations. It is also clear that none of the studies carried out in sport organizations were done in Kenya. Therefore, the effect of strategic planning and revenue diversification capacity of National Sport Federations in Kenya remained unknown. This paper presents a study undertaken in Kenya on strategic planning and revenue diversification capacity of NSFs.

\section{Statement of the Problem}

Restrictive government funding, reduced funding by corporate sponsors and increased demand from sports stakeholders has continued to constrain the funding environment for National Sports Federations (NSFs) in Kenya. Having recognized the challenges of funding NSFs against competing budgetary priorities, the government made strategic planning a policy requirement for all NSFs in Kenya since the year 2002 in the hope that this would lead to improved financial performance. This followed successes witnessed in Europe, Australia and USA among other countries where NSFs have had sound financial performance as a result of adoption of strategic planning initiatives. A number of NSFs engaged their executives together with consultants and came up with strategic plans focusing on ways of diversifying their revenue sources. However, a number of years after adoption of strategic planning, most NSFs still fail to meet their budget requirements by up to $50-60 \%$ or more leading to failure in honoring international assignments and funding local activities implying that their financial health had not improved as had been anticipated. Studies attesting to positive link between strategic planning and revenue diversification capacity have concentrated on for-profit firms whose goals are different from those of not-for profit NSFs. None the less few studies on Nonprofits including sports organizations in developed countries that are not financially sustainable show that they; have negative cash flows, lack the capacity to attract new revenue streams, and have inefficient board oversight aspects that require sound strategic planning. Revenue diversification capacity of NSFs in Kenya remained unknown. It was also unclear the extent to which managements of NSFs committed their strategic planning efforts to attracting diversified revenue streams and whether the prevailing 
INTERNATIONAL JOURNAL OF ACADEMIC RESEARCH IN ACCOUNTING, FINANCE AND

MANAGEMENT SCIENCES

Vol. 11, No. 2, 2021, E-ISSN: 2225-8329 @ 2021 HRMARS

constrained financial performance could be associated with the NSFs revenue diversification capacity. This paper presents the findings of a study conducted to analyze effect of strategic planning on revenue diversification capacity of National Sports Federations in Kenya

\section{Objective}

To analyze effect of strategic planning on revenue diversification capacity of National Sports Federations in Kenya

\section{Hypothesis}

Strategic planning has no effect on revenue diversification capacity of National Sports Federations in Kenya

\section{Theoretical Underpinnings}

According to Watt (2003) management literature has not got to grips with an overall sport management paradigm. This has created a misplaced allusion that sport management is actually different to mainstream management, that somehow the knowledge base, skill set and practice of sport management is distinct from managing in other sectors. The global trends in elite sport has proved that sport is big business on its own right and that generic management practices in other industries fit within typical sport management. Strategy relates to sports because non-sport firms have used sport strategically by advertising, sponsoring, or partnering with sport-related businesses to enhance their profitability. Similarly, sport-related businesses have been supported by variety of industries, each of which has different economic features and market forces (Ratten and Ratten, 2011). This study was guided by Markowitz's Modern Portfolio Theory (1952) and Resource Dependence Theory espoused by Pfeffer and Salancik (1978).

\section{Markowitz's Modern Portfolio Theory (1952)}

Modern portfolio theory (MPT) was developed and presented by Harry Markowitz in 1952. Markowitz (1952) stated that diversifying revenue streams will mitigate unsystematic risks over a long-term investment period. Biswas (2015) defined diversification as the reduction in portfolio volatility, which reduces the portfolio risk. Peylo (2012) defined a portfolio as the collection of assets from an investment opportunity set (IOS) and the distribution of profits from those investments. Simaan (2014) explained the main idea behind MPT is to create revenue diversification through securities that correlate with each other through a quantitative tool called mean-variance optimization (MVO).

Portfolio diversification has a different meaning in the nonprofit sector. Within the nonprofit sports sector, portfolio diversification means actively seeking different and unrelated revenue streams to hedge the risk of an unforeseen revenue uncertainty and build an adequate operating reserve (Grizzle, Sloan, \& Kim, 2015). Nonprofit sector managers have a responsibility to ensure there is enough revenue acquired to make an impact on the social mission while covering all administrative and operating costs (Charles \& Kim, 2016). The nonprofit manager's ability to evaluate which revenue streams to pursue is vital to the financial stability and future of their nonprofit business (Charles \& Kim, 2016). Poor understanding of the market and letting personal biases intervene will lead nonprofit managers to make poor decisions and ultimately waste limited resources (Ebrahim et al., 2014). In the nonprofit sports sector, revenues could be derived from traditional and non- traditional 
INTERNATIONAL JOURNAL OF ACADEMIC RESEARCH IN ACCOUNTING, FINANCE AND MANAGEMENT SCIENCES

Vol. 11, No. 2, 2021, E-ISSN: 2225-8329 ๑ 2021 HRMARS

sources which comprise both internal and external sources just like other nonprofit sectors (Stewart 2015, Mosley et al., 2012; Peylo, 2012). Investors who practice MPT concepts are thought to be strategic and rational decision makers and seek to maximize return with minimal risk (Markowitz, 1952; Shipway, 2009).

There are three basic assumptions when understanding MPT: the expected return of each asset, the expected risk of each asset, and how each will react to each other in the market (Markowitz, 1952; Shipway, 2009). Shipway (2009) explained the expected return as the annualized value expected when holding the asset over time. The next measure is risk, which is the assumption of how much the return will deviate over one year also known as volatility (Peylo, 2012; Shipway, 2009). The third basic assumption is reactivity between assets or the correlation, which compares the ups and downs in value between two investments; creating a positive or negative correlation (Shipway, 2009). NSFs invest in organized sports events with the expectation that revenue returns will be realized to sustain growth and development of the sport. Such investments are characterized by expected risk, the strategy is to have a portfolio of events that are of dissimilar risks.

National Sports Federation managers who are selecting revenue streams can incorporate MPT principles by looking at the returns, risks, and how each revenue streams react to each other (Grasse et al., 2016). Major donors, sponsors and affiliates are investors that have contributed a substantial amount of money to the NSFs and believe that the sport governing body will strive towards its mission (Khodakarami, Petersen, \& Venkatesan, 2015). While seeking other revenue streams, the NSFs managers must account for the possibility of a negative correlation between the new revenue stream and a major financial contributor (Charles \& Kim, 2016; Shipway, 2009). The correlation between revenue streams is known as reactivity and understanding this volatile relationship is a strategic imperative (Shipway, 2009). A NSF manager who understands this reactive relationship between major financial contributors' belief systems will create noncompetitive positive relationships and increase the amount of total revenue (Charles \& Kim, 2016; Khodakarami et al., 2015; Shipway, 2009)

\section{Resource Dependence Theory}

According to Pfeffer and Salancik's (1978) resource dependence theory, when resources are abundant and certain, external dependency is not problematic. However, when resources are threatened, organizations adopt strategies to ensure their continued existence. According to resource dependence theory, the most precarious situation for any organization is dependence on a single supplier for vital resources such as revenues (Pfeffer and Salancik, 1978). This is precisely the situation facing NSFs in Kenya. There have been unprecedented changes in the relationship between the NSFs and the government, apparently their main funding source in terms of international assignments, and this, in turn has created a financially constrained environment for NSFs. To survive sports organizations have to strategically enhance their capacity to diversify their revenue sources. According to Cornforth (2003b:8) organizations are dependent on other organizations for survival and therefore need to strategically manage their relationships with other organizations to ensure they get the resources and information they need. In managing these relationships, organizations enter into inter-organizational arrangements, which frequently require some loss of flexibility and autonomy in exchange for gaining control over other organizations' resources. National Sports Federations depend on a number of organizations to generate revenue streams. They often seek collaboration with government sports departments who may insist on specific line of operation if they have to attract government funding. Corporate firms who provide sponsorship may place a 
INTERNATIONAL JOURNAL OF ACADEMIC RESEARCH IN ACCOUNTING, FINANCE AND MANAGEMENT SCIENCES

Vol. 11, No. 2, 2021, E-ISSN: 2225-8329 @ 2021 HRMARS

number of demands for them to before accessing sponsorship funds. Resource dependence theory suggests that organizations seek to reduce their dependence on one source of revenue in order to balance power relations and restrict the influence of external forces on the mission and goals of the organization (Pfeffer and Salancik, 1978). Revenue diversification reduces an organization's dependency (Chang and Tuckman, 1991; Gronbjerg, 1993) by rendering it less vulnerable to the influences and demands of any single exchange partner. However, diversification of funding sources as a response to environmental threats may be dependent on the strategic planning practices adopted by sports organizations.

\section{Methodology \\ Research Design}

This study adopted both descriptive and correlation research designs. A descriptive design was used to determine the level of strategic focus with respect to NSFs' financial allocation to its potential revenue generating activities and whether this considered diversification of revenue sources. Further, the design suited the study as it enabled the researcher to establish the application of strategic planning practices by the NSFs and its effect on revenue diversification capacity (Saunders et al. 2009). Correlation was deemed fit for the study since it helped test the hypothesis to establish relationship between the variables.

\section{Area of Study}

This study was carried out in Kenya among the National Sports Federations.

\section{Target Population}

The target population was 156 officials drawn from 39 active NSFs in Kenya who are affiliated to National Olympic Committee of Kenya (NOCK) and Kenya National Sports Council.

\section{Sampling Design}

Both purposive and random sampling techniques were employed. Four officials from each federation were purposively picked, specifically; the chairman, secretary, treasurer and organizing secretary (fixtures secretary) who form the top executive committee of the NSFs. They were considered as key respondents being centrally involved in planning. A random sampling technique was considered suitable as it provided each NSF official with an equal chance of being selected for the study.

\section{Data Collection}

Both Primary and Secondary data were used in this study. Primary data constituted responses from NSFs officials while secondary data was drawn from documents and records kept by NSFs. Primary and secondary data were collected using questionnaire and protocol sheets respectively. The structured questionnaire consisted of close-ended Likert-type questions which made it easier to administer. It had pre-determined response choices to guide the respondents so as to obtain consistent responses. It was also less costly to administer and the respondents' choices were not influenced by the data collectors as might be the case with other qualitative instruments. 


\section{Data Instruments; Reliability and Validity}

The questionnaire items were subjected to pre-testing through pilot study using 12 respondents from 3 NSFs that were not included in the main study in order to ascertain reliability and validity before embarking on the main study. Reliability was tested using internal consistency and registered Cronbach alpha value of between 0.781 to 0.926 implying that the test items correlate highly among themselves and had consistency in measuring the concept of interest. Face and construct validity was qualitative assessed by asking the opinion of officials used in the pilot, strategic planning professionals and professors from Maseno University School of Business and Economics on the suitability and adequacy of the research instruments.

\section{Data Analysis}

Descriptive and inferential statistical techniques were employed in data analysis. The descriptive statistics run were percentages. Inferential statistical analysis involved the use of Pearson Correlation and multiple linear regression analysis. Presentation was in form of charts and tables.

Multiple Regression Model Specification

$Y_{i}=\beta_{0}+\beta_{1} X_{1 i}+\beta_{2} X_{2 i}+\ldots+\beta_{p} X_{p i}+\varepsilon_{i}$

Where:

$\mathrm{Y}_{\mathrm{i}} \quad=$ dependent variable

$\beta_{0}=$ Constant term

$\beta_{1} \ldots \beta_{p}=$ Coefficients relating to $p$ explanatory variables of interest.

$\varepsilon_{\mathrm{i}} \quad=$ Error term i.e. residual representing deviations of the observed value of the response variable from that approximated by the model.

Multiple regressions helped in testing the extent to which components of strategic planning influenced the Revenue Diversification individually and when they were put together. To cater for other variables that may not be explicitly measured and put in the model an error term was included. It assumed that; the relationship between the dependent and independent variables were linear, absence of correlation between the independent variables stated and that data for the variables had a normal distribution (Allan, 2008). Revenue Diversification (dependent variables) was conceptualized as being influenced by the sub variables of strategic planning namely; establishing strategic planning Platform; formulating financing strategies; developing clear implementation framework; and monitoring and evaluation (Barney, 1991; Shapiro, 1995). In model form this was stated as

$$
Y_{w t i}=\beta_{0}+\beta_{1} S P P_{1 i}+\beta_{2} F_{2 i}+\beta_{3} I F_{3 i}+\beta_{4} M E_{4 i}+\varepsilon_{i}
$$

Where:

$\mathrm{Y}_{\mathrm{wti}}=$ Weighted revenue diversification capacity for five years $\left(\mathrm{Y}_{\mathrm{i}}=\right.$ revenue diversification capacity)

$\beta_{\mathrm{i}} \quad=$ Parameters to be determined $(i=0,1,2,3,4)$

$\mathrm{SPP}_{1 \mathrm{i}}=$ Strategic Planning platform corresponding to the revenue diversification capacity

$\mathrm{FS}_{2 \mathrm{i}} \quad$ = Financing strategies corresponding to the revenue diversification capacity

$\mathrm{IF}_{3 \mathrm{i}} \quad=$ Implementation framework corresponding to the revenue diversification capacity

$\mathrm{ME}_{4 \mathrm{i}}$ = Monitoring and Evaluation corresponding to the revenue diversification capacity

$\mathrm{W} \quad=$ Weighted average of revenue diversification capacity for five years.

$\mathrm{t} \quad=$ Time period (5 years) within which data was considered. 
INTERNATIONAL JOURNAL OF ACADEMIC RESEARCH IN ACCOUNTING, FINANCE AND

MANAGEMENT SCIENCES

Vol. 11, No. 2, 2021, E-ISSN: 2225-8329 @ 2021 HRMARS

$\varepsilon_{\mathrm{i}} \quad=$ Error term i.e. residual representing deviations of the observed value of the response variable from that approximated by the model.

Model 3.2 was based on the assumption that revenue diversification capacity as a variable was independent of each omitted variable, error term was normally distributed, the combined effect of the omitted variables had zero expectation and that the combined effect of the omitted variables did not affect the stated variable across the subjects.

\section{Results}

\section{Response Rate}

Out of a sample of 144 a total of 112 respondents returned filled questionnaires giving a response rate of $77.80 \%$ which was considered sufficient for a scientific study.

\section{Effect of Strategic Planning on Revenue Diversification Capacity}

Revenue Diversification capacity was conceptualized in terms of constructs which measure innovative use of traditional sports revenue sources alongside non-traditional sources. It was also approached from National Sports Federations' officials' effectiveness in allocation of their financial resources towards activities that yield more revenues (Stewart, 2007). For ease of analysis revenue sources were grouped under four categories namely; borrowings, corporate sponsorship, government support and operations. Within each category both traditional and non-traditional sources were considered. Financial allocation was assessed in terms of sports development, facility and equipment acquisition, administration and, marketing and promotion. Under each area the study was keen on the relative allocative importance given to revenue generation compared to routine management issues. Analysis was done descriptively using weighted mean percentages; and inferential analysis was done using Pearson correlation coefficient and multiple regression equation 3.1.

\section{Annual Allocation of Financial Resources by National Sport Federations in Kenya}

Analysis of the NSFs income statements helped in establishing how they allocated their financial resources. The purpose of evaluating allocation (utilization) of financial resources was to determine the level of strategic focus with respect to diversification of revenue sources. The analysis of the allocations of financial resources was done using weighted mean percentages and results presented as shown in Figure 4.1. 


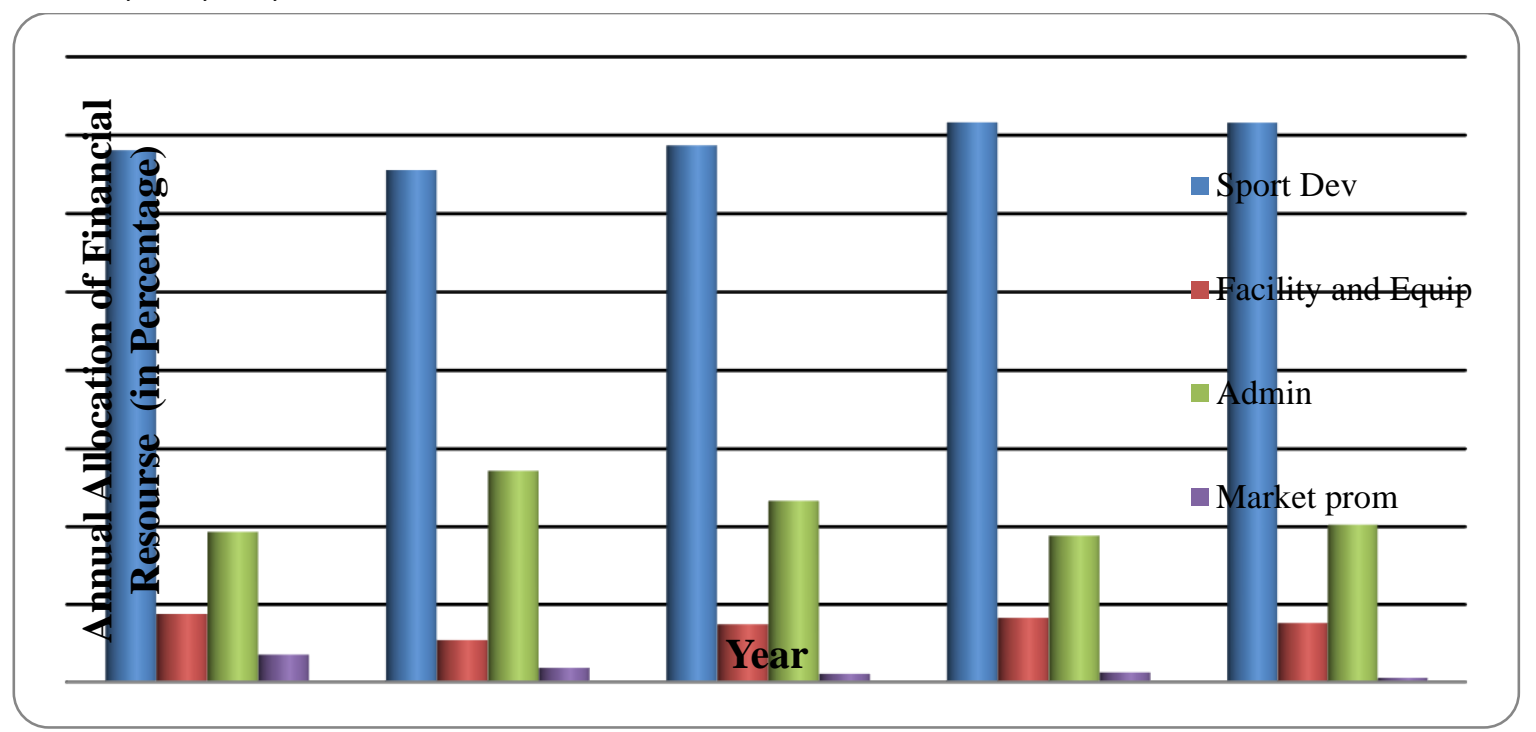

Figure 4. 1: Annual Allocations of the Financial Resources by NSFs

Source: NSFs Financial Data (2009-2013)

Results in Figure 4.1 show that the allocation of the federations' financial resources was mainly in four areas. Among the four areas of resource allocation, sports development was allocated the largest share of resources each year by each NSF (65\% - 70\%) followed by administration, taking between (19\%-25\%) while facility and equipment improvement, and marketing and promotions took the least share of below $10 \%$ each year. This showed that most of the NSFs tend to lay emphasis on sports development. Whereas sports development is encompassing remarks from the NSFs officials revealed that they mainly concentrated on organizing tournaments where affiliate clubs are invited to compete. Despite this being a source of revenue which may be generated through participation fees, these very sources are restricted in terms of the number of teams and facilities such as stadia where gate ticketing may effectively be administered. Furthermore, most NSFs do not have control over individual player development, and formation and sustainability of clubs leave alone being assured of their participation in the federation organized tournaments. It can therefore be concluded that most national sports federations in Kenya seem to be operating mainly at Amateur Sports Planning Model as described by Stewart (2007) and have not built revenue diversification capacity. Some of them could be described as embracing the Traditional Professional Sports Planning Model as described by Andreff (1992) but with less emphasis on attracting the members and fans through facility improvement and marketing efforts. However, the changes in yearly allocations per item were not significantly different over the five year period, indicating that the national sports federations were not innovative in terms of resource allocation to enhance revenue diversification.

\section{Revenue sources of National Sport Federations in Kenya}

The changes in the revenue sources of the federations were used as one of the indicators for analyzing revenue diversification capacity of national sports federations. The extent of change in revenue diversification capacity was in turn determined by analyzing the changes in the sources for the NSFs over a five year period. Analysis of the balance sheets of NSFs helped determine their 
INTERNATIONAL JOURNAL OF ACADEMIC RESEARCH IN ACCOUNTING, FINANCE AND

MANAGEMENT SCIENCES

Vol. 11, No. 2, 2021, E-ISSN: 2225-8329 @ 2021 HRMARS

revenue sources. Analysis was done using percentages to provide averaged revenue sources of NSFs in Kenya between 2009-2013 and results presented in Table 4.1.

Table 4.1: Averaged components of revenue sources of NSFs

\begin{tabular}{llllll}
\hline $\begin{array}{l}\text { Revenue } \\
\text { Source }\end{array}$ & Borrowing & $\begin{array}{l}\text { Corporate/NOC- } \\
\text { K/ Sponsorships }\end{array}$ & $\begin{array}{l}\text { Government } \\
\text { Support }\end{array}$ & $\begin{array}{l}\text { Operation } \\
\text { Total }\end{array}$ & \\
Proportion & $25.16 \%$ & $28.36 \%$ & $16.38 \%$ & $30.10 \%$ & $100 \%$ \\
\hline
\end{tabular}

Source: NSFs Financial Data (2009-2013)

Results in Table 4.1 show that over the five year period the main source of revenue for the NSFs was operations (30.10\%) followed by sponsorship (28.36\%). The percentages from borrowing was (25.16) while government support accounted for (16.38) of the averaged composition of revenue sources. The results show that NSFs in Kenya largely rely on external revenue sources which constitute $69.90 \%$ leaving only $30.10 \%$ being generated internally from federation activities. The implication of this is a clear manifestation of lack of revenue diversification since the managements of the federations have to depend on the limited external sources to realize their sporting goals. Further, sponsorship that constitute the second largest source $(28.36 \%)$ is normally pegged on marketing promotional interests of very few commercial firms and the revenues generated from such sponsors only met operating expenses of specific sponsored events. Support from NOC-K and government only come in a limited way when a national team of a federation qualifies for international assignments and through occasional training programmes for administrators and coaches. Borrowings are often in form of unpaid for services such as hire of stadia, accommodation for national teams during preparations and championships and rent for office space among others hence, do not help in acquisition of assets that could help diversify sources of revenue. Comments from the respondents indicated that the $30.10 \%$ revenue from NSFs operations mainly came from tournament participation fees and annual affiliation fee paid by clubs. The only other source which is limited and unreliable is gate ticketing where tournaments are held at venues with enclosed stadia. The findings mean that NSFs are unable to generate revenue through effective strategic planning which would enable them to diversify potential revenue streams from the sports spectacles themselves contrary to a position espoused by Andreff (1992) for a sustainable revenue base.

The revenue trends revealed by NSFs from the analyses (Table 4.1) agree with Slack (1998) who observed that Canadian sport federations have been the least successful to replace state funding with corporate financial support and were showing signs of returning to the 'kitchen table' type of design associated with very limited revenue sources. This organizational design shows a handful of charismatic volunteers who manage the policies, programs and finances of the organization with little planning and informal rules, regulations, decision making and communication (Kikulis et al, 1992). Sport federations that operate at the level of the 'kitchen' table model have very little revenue diversification capacity and often rely on government funding to host any international event leave alone participating abroad (Andreff, 1992).

\section{Correlation between Strategic Planning and Revenue Diversification Capacity}

Correlation analysis was used to test for linearity and the strength of the relationship between the specific strategic planning variables (Establish strategic planning platform, Formulating financing 
INTERNATIONAL JOURNAL OF ACADEMIC RESEARCH IN ACCOUNTING, FINANCE AND

MANAGEMENT SCIENCES

Vol. 11, No. 2, 2021, E-ISSN: 2225-8329 ๔ 2021 HRMARS

strategies, Strategy implementation, Monitoring and evaluation) and the components of the revenue diversification capacity (allocation of financial resources and the revenue sources) for the NSFs in Kenya. Results are presented in Table 4.2.

Table 4.2: Correlation between strategic planning and Revenue Diversification

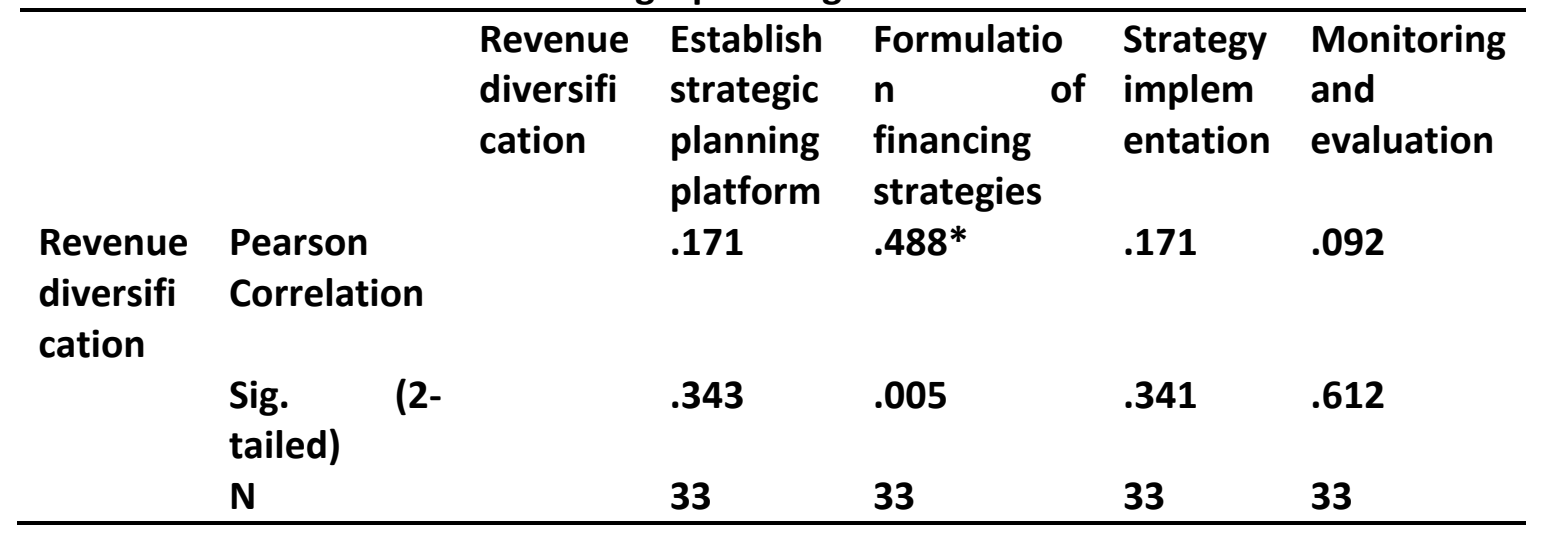

Source: Survey Data (2014)

Table 4.2 revealed that there was only one component of strategic planning which was significant and positively correlated with revenue diversification capacity. The notable correlation was between formulation of financing strategies and revenue diversification capacity $(r=0.488 ; p=0.005)$. The results relate revenue diversification to formulation of financing strategies leaving out other important components such as establishing strategic planning platform, strategy implementation, and monitoring and evaluation. The result implies that the NSFs in Kenya although formulate strategies aimed at diversifying their revenue base, they do not consider relevance of financing strategies to their industry environment which would be revealed by establishing strategic planning platform. The financing strategies are also not consistently implemented and consequently not monitored and evaluated. It further confirms that the NSFs in Kenya are still operating in the Amateur (Kitchen table model) of sports planning (Stewart, 2007; Andreff, 1992) which is characterized by limited revenue diversification. This situation revealed by the current study in the NSFs in Kenya is consistent with previous observations by (Andreff \& Staudohar, 2000; Winand, 2009) who asserted that sport federations with constrained financial performance had a problem with their revenue diversification capacity.

\section{Effect of Strategic Planning on revenue Sources}

Regression analysis was used to test the extent to which the independent variables of strategic planning influenced the dependent variable (revenue sources) which provides an easily observable evidence of revenue diversification capacity of an organization. The results were as shown in Table 4.3. 
INTERNATIONAL JOURNAL OF ACADEMIC RESEARCH IN ACCOUNTING, FINANCE AND MANAGEMENT SCIENCES

Vol. 11, No. 2, 2021, E-ISSN: 2225-8329 @ 2021 HRMARS

Table 4. 3: Effect of strategic Planning on revenue Sources

\begin{tabular}{|c|c|c|c|c|c|c|}
\hline \multirow[t]{2}{*}{ Model } & & \multicolumn{2}{|c|}{$\begin{array}{l}\text { Unstandardized } \\
\text { Coefficients }\end{array}$} & \multirow{2}{*}{$\begin{array}{l}\text { Standardized } \\
\text { Coefficients } \\
\text { Beta }\end{array}$} & \multirow[t]{2}{*}{$t$} & \multirow[t]{2}{*}{ Sig. } \\
\hline & & B & $\begin{array}{l}\text { Std. } \\
\text { Error }\end{array}$ & & & \\
\hline (Constant) & & 1.574 & .995 & & 1.58 & .124 \\
\hline $\begin{array}{l}\text { Overall } \\
\text { Planning }\end{array}$ & Strategic & .189 & .308 & .110 & $\begin{array}{l}2 \\
.614\end{array}$ & .544 \\
\hline$R$ & .110 & & & & & \\
\hline $\mathrm{R}^{2}$ & .012 & & & & & \\
\hline Adjusted $\mathrm{R}^{2}$ & .020 & & & & & \\
\hline $\mathrm{F}$ & 14.213 & & & & & \\
\hline
\end{tabular}

a. Dependent Variable: Revenue Sources

b. Predictors: Overall Strategic Planning

Source: Survey Data (2014)

Table 4.3 presents results of regression analysis of revenue sources as affected by strategic planning. The results show that the effect is insignificant $(B=0.189$, Beta $=0.110 ; p=0.544)$ although there is a positive relationship between strategic planning and financial sources $(R=0.110)$. The $R 2$ value of 0.012 indicates that strategic planning influenced only $1.20 \%$ of the decisions on financial sources in the case of NSFs in Kenya; the low contribution of strategic planning to decisions on revenue sources shows that revenue diversification is not influenced by strategic planning. This contradicts Smith and Stewart (1999) and Gerrard (2005) who both agree that improvement in revenue generation for a sport organization can be achieved by enhancing revenue diversification capacity and cost reduction strategy arising from managerial planning effectiveness and efficiency. From the results, NSFs in Kenya seem to pursue sporting objectives more than financial success hence, their low revenue diversification capacity. This perhaps explains why NSFs in Kenya are constrained financially. This is consistent with views of Wicker and Breuer (2013); Barajas and Rodriguez (2010); and Dietl and Franck (2007) who assert that sports organizations that placed more emphasis on sporting objectives at the expense of financial success were often cash trapped and in turn ended up failing to realize sporting success.

\section{Conclusion and Recommendation}

Results showed that effect of strategic planning on revenue diversification capacity is not significant although there is a positive relationship between strategic planning and revenue diversification capacity measured in terms of financial sources. Results of correlation analysis were mixed with two components of strategic planning being significant (formulating financing strategies and monitoring and Evaluation) leaving out other two components of strategic planning (establishment of the strategic planning platform and strategy implementation) which is contradictory since the components complement one another. Regression analysis confirmed that strategic planning had a 
INTERNATIONAL JOURNAL OF ACADEMIC RESEARCH IN ACCOUNTING, FINANCE AND

MANAGEMENT SCIENCES

Vol. 11, No. 2, 2021, E-ISSN: 2225-8329 @ 2021 HRMARS

positive effect on revenue diversification although the relationship was insignificant. Results from descriptive analysis showed that NSFs had low revenue diversification capacity.

This study recommends that NSFs in Kenya need to diversify their revenue sources. Improved revenue diversification capacity arising from sound strategic planning effort will lead to improved financial performance

\section{References}

Allan, S. (2008). An Introduction to Regression Analysis. The Inaugural coarse lecture. University of Chicago, the Law School.

Andreff, W. (1992). The Evolving European Model of Professional Sports Finance. European Sports Management Quarterly.

Barajas, A., \& Rodriguez, P. (2010). Spanish football clubs' finances: Crisis and player salaries. International Journal of Sport Finance, 5, 52-66.

Biswas, D. (2015). The effect of portfolio diversification theory: Study on Modern Portfolio Theory of stock investment in the national stock exchange. Journal of Commerce \& Management Thought, 6, 445-455. doi:10.5958/0976-478X.2015.00027.0

Carroll, D. A., Stater, K. J. (2009). Revenue diversification in nonprofit organizations: Does it lead to financial stability? J. Publ. Adm. Res. Theory., 19, 947-966.

Chang, C. F., \& Tuckman, H. P. (1996). Revenue diversification among non-profits.

VOLUNTAS: International Journal of Voluntary and Nonprofit Organizations, 5, 273-290.

Charles, C., \& Kim, M. (2016). Do donors care about results? An analysis of nonprofit arts and cultural Organizations. Public Performance \& Management Review, 39, 864-884. doi:10.1080/15309576.2015.1137775

Cornforth, C. (2003b:8). The governance of public and non-profit organizations: What do boards do? London: Routledge.

Dietl, H., \& Franck, E. (2007). Governance failure and financial crisis in German football. Journal of Sports Economics, 8(6), 662-669.

Ebrahim, A., Battilana, J., \& Mair, J. (2014). The governance of social enterprises: Mission drift and accountability challenges in hybrid organizations. Research in Organizational Behavior: An Annual Series of Analytical Essays and Critical Reviews, 34, 81-100. doi:10.1016/j.riob.2014.09.001

European Union Commission. (2011). Study on the funding of grassroots sports in the EU. Volume I of the Final report.

Ferkins L., Shilbury D., \& McDonald, G. (2005). The Role of the Board in Building Strategic Capability: Towards an Integrated Model of Sport Governance Research. Sport Management Review.

Fischer, R. L., Wilsker, A., \& Young, D. R. (2011). Exploring the revenue mix of non profit organizations: Does it relate to publicness? Nonprofit and Voluntary Sector Quarterly, 40(4), 662-681

Galaskiewicz, J., \& Bielefeld, W. (1998). Nonprofit organizations in an age of uncertainty: A study of organizational change. New York: Aldine de Gruyter.

Gerrard, W. (2004), Sport Finance, in Beech, J. and Chadwick, S. (Eds), the Business of Sport Management, Pearson Education, Edinburgh Gate.

Grasse, N. J., Whaley, K. M., \& Ihrke, D. M. (2016). Modern portfolio theory and nonprofit arts organizations. Nonprofit \& Voluntary Sector Quarterly, 45, 825-843. 
INTERNATIONAL JOURNAL OF ACADEMIC RESEARCH IN ACCOUNTING, FINANCE AND

MANAGEMENT SCIENCES

Vol. 11, No. 2, 2021, E-ISSN: 2225-8329 @ 2021 HRMARS

doi:10.1177/0899764015603204

Greenlee, J., \& Trussel, J. (2000). Estimating the financial vulnerability of charitable organizations. Nonprofit Management and Leadership, 11(2), 199-210.

Grizzle, C., Sloan, M. F., \& Kim, M. (2015). Financial factors that influence the size of nonprofit operatingreserves. Journal of Public Budgeting, Accounting \& Financial Management, 27(1), $67-$ 97. Retrieved from http://pracademics.com/index.php/jpbafm

Gronbjerb, K. A. (1993). Understanding Nonprofit Funding. San Francisco: Jossey-Bass.

Hoye, R. (2006). Leadership within Australian Voluntary Sport Organization Boards. Non-profit Management \& Leadership, 16(3), 297-313.

Hoye, R., \& Cuskelly, G. (2007). Sport Governance, Butterworth-Heinemann, Elsevier Burlington, USA.

Keating, E. K., Fischer, M., Gordon, T. P., \& Greenlee, J. (2005). Assessing the financial vulnerability in the nonprofit sector. Working Paper No. 27, Harvard University, the Hauser Center for Nonprofit Organizations.

Kikulis, L. M., Slack, T., \& Hinings, B. (1992). Institutionally Specific Design Archetypes: A Framework forUnderstanding Change in National Sport Organizations, International Review for the Sociology of Sport, 27 (4), 343-368.

Khodakarami, F., Petersen, J. A., \& Venkatesan, R. (2015). Developing donor relationships: The role of thebreadth of giving. Journal of Marketing, 79(4), 77-93. doi:10.1509/jm.14.0351

Markowitz, H. M. (1952). Portfolio selection. Journal of Finance, 7, 77-91.

Mosley, J. E., Maronick, M. P., \& Katz, H. (2012). How organizational characteristics affect the adaptivetactics used by human service nonprofit managers confronting financial uncertainty. Nonprofit Management \& Leadership, 22, 281-303. doi:10.1002/nml.20055

Peters, M. (2004). Planning in Sport- A good practice guide for sporting organizations. Australian Sports Commission.

Peylo, B. T. (2012). A synthesis of modern portfolio theory and sustainable investment. Journal of Investing, 21(4), 33-46. Retrieved from http://www.iijournals.com/toc/joi/current

Pfeffer, J., \& Solancik, G. (1978). The external control of organizations: A resource dependence perspective. New York: Harper and Row.

Ratten, V., and Ratten, H., (2011). International sport marketing: practical and future research implications. Journal of Business \& Industrial Marketing, 26(8), 614-620.

Saunders, M., Lewis, P., \& Thornhill, A. (2009). Research methods for business students. Harlow, Pearson Education.

Shipway, I. (2009). Modern Portfolio Theory. Trusts \& Trustees, 15(2), 66-71. doi:10.1093/tandt/ttn129

Simaan, Y. (2014). The opportunity cost of mean-variance choice under estimation risk. European Journalof Operational Research, 234, 382-391. doi:10.1016/j.ejor.2013.01.025

Slack, T. (1998). Studying the commercialization of sport: The need for critical analysis, Sociology of Sport On-Line, 1(1), http://physed.otago.ac.nz/sosol/v1i1/v1i1a6.htm.

Smith, A., \& Stewart, R. (1999). Sport Management: A guide to professional Practice. London: Allen and Unwin

Stewart, B. (2007). Sport Funding and Finance. Oxford: Elsevier.

Stewart, B. (2015). Sport Funding and Finance. Second edition, Routledge, New York.

Tuckman, H. P., \& Chang, C. F. (1991). A methodology for measuring the financial vulnerability of charitable non-profit organizations. Nonprofit and Voluntary Sector Quarterly, 20, 445-460. 
INTERNATIONAL JOURNAL OF ACADEMIC RESEARCH IN ACCOUNTING, FINANCE AND

\section{MANAGEMENT SCIENCES}

Vol. 11, No. 2, 2021, E-ISSN: 2225-8329 @ 2021 HRMARS

Trussel, J. M. (2002). Revisiting the prediction of financial vulnerability. Nonprofit Management and Leadership, 13(1), 17-31.

Watt, C. D. (2003). Sports Management and Administration, $2^{\text {nd }}$ Ed. Routledge, London.

Wicker, P., \& Breuer, C. (2013). Understanding the importance of organizational resources to explain organizational problems: Evidence from non-profit sport clubs in Germany. VOLUNTAS: International Journal of Voluntary and Nonprofit Organizations, 24(2), 461-484.

Winand, M. (2009). Determinants of organizational performance in sport federations: a compared analysis of the French speaking sport federations in Belgium. Unpublished doctoral dissertation, Université catholique de Louvain, Louvain-laNeuve, Belgium.

Jason, W. A., \& Rosentraub, M. S. (2012). Sports Finance and Management, CRC press, London. 